International Journal of Life Sciences
Available online at www.sciencescholar.us
Vol. 4 No. 2, August 2020, pages: $32-41$
e-ISSN: 2550-6986, p-ISSN: $2550-6994$
https://doi.org/10.29332/ijls.v4n2.432

\title{
The Effect of Chopped Corm Sizes and Types of Soaking Material on Growth Seedling of Kepok Banana (Musa paradisiaca L. ABB Kepok)
}

\author{
(CrossMark \\ I Nyoman Rai a, I Made Sudana ${ }^{\text {b }, ~ I ~ N y o m a n ~ G e d e ~ A s t a w a ~ c, ~ R i n d a n g ~ D w i y a n i ~}{ }^{\mathrm{d}}$ \\ Manuscript submitted: 27 May 2020, Manuscript revised: 09 June 2020, Accepted for publication: 18 July 2020
}

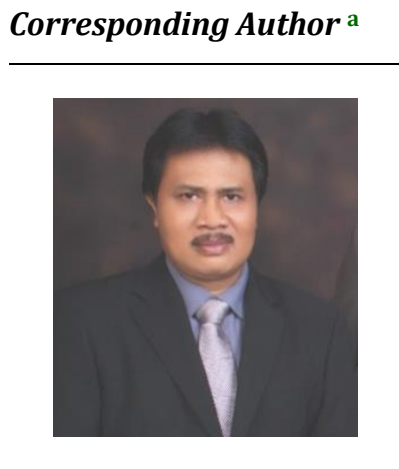

Keywords

$B A ;$

chopped corm size;

Kepok banana;

NAA;

seedling and soaking;

\begin{abstract}
This research was conducted to study the effect of chopped corm sizes and types of soaking material on growth seedling of Kepok banana. The study was conducted at green house used a factorial randomized block design with 2 treatment factors. The first factor was chopped corm sizes (in length $\mathrm{x}$ width $\mathrm{x}$ height), consists of 3 levels i.e. small size $5 \times 5 \times 5 \mathrm{~cm}\left(\mathrm{~B}_{1}\right)$, medium size $7 \times 7 \times 7$ $\mathrm{cm}\left(\mathrm{B}_{2}\right)$, and large size $9 \times 9 \times 9 \mathrm{~cm}\left(\mathrm{~B}_{3}\right)$. The second factor was types of soaking material, consists of 4 levels i.e. soaked in water only $\left(\mathrm{R}_{0}\right)$, soaked with Dithane M-45 fungicide $2 \mathrm{~g} / \mathrm{l}\left(\mathrm{R}_{1}\right)$, soaked with Dithane M-45 fungicide $2 \mathrm{~g} / \mathrm{l}+\mathrm{NAA}$ hormone $100 \mathrm{ppm}\left(\mathrm{R}_{2}\right)$, soaked with Dithane $\mathrm{M}-45$ fungicide $2 \mathrm{~g} / \mathrm{l}+\mathrm{BA}$ hormone $75 \mathrm{ppm}\left(\mathrm{R}_{3}\right)$, and soaked with the Dithane $\mathrm{M}-45$ fungicide $2 \mathrm{~g} / \mathrm{l}+$ NAA hormone $100 \mathrm{ppm}+\mathrm{BA} 75 \mathrm{ppm}\left(\mathrm{R}_{4}\right)$. The result showed that the combination treatment of $9 \times 9 \times 9 \mathrm{~cm}$ chopped corm size and soaking with Dithane M-45 $2 \mathrm{~g} / \mathrm{l}+\mathrm{BA}$ hormone $75 \mathrm{ppm}$ resulted in the highest growth of Kepok banana seedling, indicated by the highest height and dry-oven weight of seedling.
\end{abstract}

\section{Contents}

Abstract

\footnotetext{
${ }^{a}$ Agroecotechnology Study Program, Faculty of Agriculture, Udayana University, Indonesia.

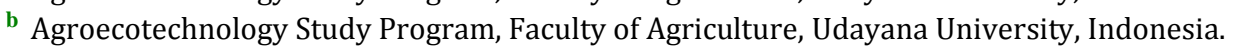

c Agroecotechnology Study Program, Faculty of Agriculture, Udayana University, Indonesia.

d Agroecotechnology Study Program, Faculty of Agriculture, Udayana University, Indonesia.
} 


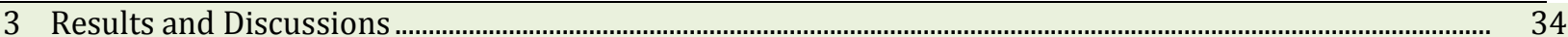

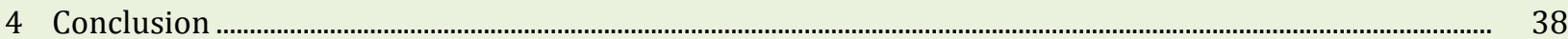

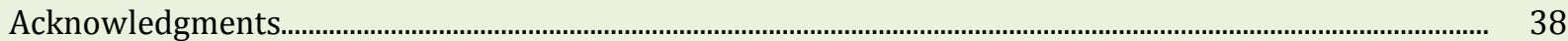

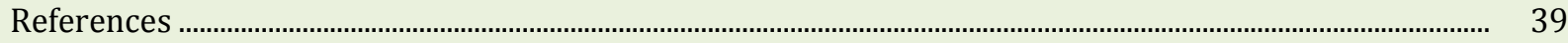

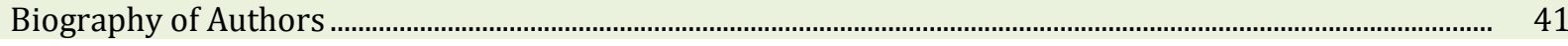

\section{Introduction}

Bananas are classified as important fruit plants in Indonesia. This plant is widely cultivated not only in the yard or in the garden on a small scale but also cultivated as a plantation crop on a commercial scale. Also, Indonesia is one of the countries with the highest diversity of bananas in the world (Convention on Biological Diversity, 2017). According to Prabawati et al. (2008) in Indonesia, there are 230 types of bananas, spread throughout the province so that almost all regions in Indonesia produce bananas. Indonesian banana production is also high and ranks sixth in the world, but in global banana exports, it ranks only $60^{\text {th }}(\mathrm{FAO}, 2018)$.

Kepok Banana (Musa paradisiaca L. ABB Kepok) is the result of a cross between Musa acuminata with the AA genome and Musa balbisiana with the ABB genome (Wahyuningtyas, 2009; Carmona-Garcia et al., 2009; Borges et al., 2005; Pelissari et al., 2013). Kapok banana is one type of banana that has high economic value because of its high adaptability (Rai et al., 2018), its use is very broad that can be consumed directly or as processed material which has good taste and sweetness (sugar content reaches 300 \%brix) (Kasrina, 2013; Valentine et al., 2015). According to Israel et al. (2015), countries that process bananas into chips and banana cakes, 95\% of them use the type of Kepok banana. Reginio et al. (2018) stated that the Kapok banana is classified as a very important and popular type of banana compared to other banana cultivars so that it is widely developed in various countries, especially in Southeast Asia.

Banana production in Indonesia over the past 5 years has decreased very dramatically, from 82.27 tons in 2015 to 68.82 tons in 2019 (Deptan, 2020). Besides due to high pest and diseases attacks, one of the obstacles in the development of bananas in Indonesia is the difficulty in obtaining vigorous and healthy seedling in sufficient quantities as needed.

Propagation of banana seedlings can be done by separating tillers, using chopped corm and tissue culture techniques. Each method has both advantages and disadvantages. The method of separating tillers from banana clumps is easy, but produces non-uniform seedlings and can cause disease for the main plants and seedlings taken as a result of the wound due to separation (Tumuhimbise \& Talengera, 2018). Propagation through tissue culture can produce uniform seedling in large quantities over time but requires high capital, skill requirements and somaclonal variations often occur (Kasyoka et al., 2010). Propagation by chopped corm produces fewer seedlings than tissue culture, but the costs are lower and skills are less so that it is more easily applied by farmers (Nyawira et al., 2017; Prabhuling \& Sathyanarayana, 2017; Kishor et al., 2017; Tumuhimbise \& Talengera, 2018). With these considerations, this research tries to produce vigorous and healthy Kapok banana seedlings using different chopped corms size.

Banana corm is an organ called "tuberous rhizome" which acts as a true stem on the banana plant, located underground just above the pseudostem (Bhende \& Kurien, 2015; Nunez-Santiago et al., 2004; Parmar \& Kar, 2007). The chopped corm can be used as a source of propagation for seedlings because of the presence of side nodes that have the potential to grow into juvenile bananas. One obstacle in the multiplication by using corm is the limited number of parts of chopped corm that are obtained because from one chopped corm will grow just one bud that will later grow into one vigorous and healthy banana seedling. According to Dewi (2016), the size of the chopped corm that is too large will require a wider nursery space, causing the inefficient production of large-scale seedlings. For that, it is necessary to try the use of different sizes of the chopped corm.

To ensure that the buds of the chopped corms can grow properly, it is necessary to protect the buds from infection with fungicides and stimulate the growth of buds by immersion in growth hormones. The results of Firmansyah (2011) showed that immersion with Dithane M-45 fungicide concentration of $2 \mathrm{~g} / \mathrm{l}$ in Kepok banana nurseries was able to reduce fungus attacks compared without immersion of fungicides. Saputra (2016) found that the immersion of chopped corm of Kapok Kuning banana with hormone benzyl adenine (BA) concentration of 50-100 ppm significantly increased bud growth. The same thing was obtained by Sukowardana et al. (2015) that giving of BA 50,100, and $150 \mathrm{ppm}$ concentrations in Kepok Manado bananas significantly increased

Rai, I. N., Sudana, I. M., Astawa, I. N. G., \& Dwiyani, R. (2020). The effect of chopped corm sizes and types of soaking material on growth seedling of kepok banana (Musa paradisiaca L. ABB Kepok). International Journal of Life Sciences, 4(2), 32-41. https://doi.org/10.29332/ijls.v4n2.432 
seedling growth compared to control. Besides soaking with BA, soaking with auxin hormone is estimated can increase the growth of banana seedlings in the multiplication with chopped corm. According to Mahfudza et al. (2018), the use of NAA concentrations of $1-5 \mathrm{ppm}$ in in-vitro Cavendish banana propagation increased the number of buds and roots compared to controls. Avivi et al. (2013) stated that giving $0.5 \mathrm{ppm}$ NAA concentration increased root length and number of roots in the propagation of Raja, Kepok, and Mas bananas with tissue culture, with an acclimatization success rate reaching $90 \%$.

\section{Materials and Methods}

The study was conducted at green house in the Experimental Field of Faculty of Agriculture Udayana University, from February to May 2020. Analysis of variables conducted at Laboratory of Integrated Service, Faculty of Agriculture Technology Udayana University, and Laboratory of Agronomy \& Horticulture and Laboratory of Soil Science Faculty of Agriculture Udayana University. The study used a factorial randomized block design (RBD) with 2 treatment factors. The first factor was chopped corm sizes (in length $\mathrm{x}$ width $\mathrm{x}$ height), consists of 3 levels i.e. small size $5 \times 5 \times 5 \mathrm{~cm}\left(\mathrm{~B}_{1}\right)$, medium size $7 \times 7 \times 7 \mathrm{~cm}\left(\mathrm{~B}_{2}\right)$, and large size $9 \times 9 \times 9 \mathrm{~cm}\left(\mathrm{~B}_{3}\right)$. The second factor was types of soaking material for chopped corm consists of 4 levels i.e. soaked in water only $\left(\mathrm{R}_{0}\right)$, soaked with Dithane M-45 fungicide $2 \mathrm{~g} / \mathrm{l}\left(\mathrm{R}_{1}\right)$, soaked with Dithane M-45 fungicide $2 \mathrm{~g} / \mathrm{l}+\mathrm{NAA}$ hormone $100 \mathrm{ppm}\left(\mathrm{R}_{2}\right)$, soaked with Dithane M-45 fungicide $2 \mathrm{~g} / \mathrm{l}+\mathrm{BA}$ hormone $75 \mathrm{ppm}\left(\mathrm{R}_{3}\right)$, and soaked with the Dithane M-45 fungicide $2 \mathrm{~g} / \mathrm{l}+\mathrm{NAA}$ hormone $100 \mathrm{ppm}+\mathrm{BA} 75 \mathrm{ppm}\left(\mathrm{R}_{4}\right)$. Thus, there were 12 combination treatments and each was repeated 3 times.

Corm of Kepok banana was taken from the parent banana whose fruit has been harvested. The corm washed clean then air-dried, after that cut with the size according to the treatment of chopped corm size. The chopped corms then soaked according to the type of soaking material treatments. Technical immersion in the treatment of $\mathrm{R}_{0}$, chopped corm soaked in water for 30 minutes, on $\mathrm{R}_{1}$ soaked with Dithane M- 45 for 10 minutes then dried, in $R_{2}$ soaked with Dithane M-45 for 10 minutes then dried for 10 minutes, then soaked again in 100 ppm NAA hormone solution for 1 minute and then air-dried. In $\mathrm{R}_{3}$ soaked with Dithane M- 45 for 10 minutes, then airdried for 10 minutes, after which they have soaked again in a 75 ppm BA hormone solution for 1 minute. In $\mathrm{R}_{4}$, the chopped corm soaked with Dithane M-45 for 10 minutes, air-dried for 10 minutes, then soaked with 100 ppm NAA for 1 minute after that drained for 3 minutes, then soaked again at BA 75 ppm for 1 minute. The chopped corms that have been immersed then planted in a polybag.

Planting begins with the preparation of planting media. The planting media was a mixture of soil, husks, and manure with a composition of 1:1:1 (v:v:v). Planting media was put into a $5 \mathrm{~kg}$ polybag until full. Chopped corms that have been given immersion treatment were planted in polybags with a depth of 3-5 cm from the surface. Maintenance was carried out intensively including watering, pest and diseases, and weed control.

The experiment ended 3 months after planting the chopped corms, with the criteria that the banana seedlings are ready to be moved to the field and with the minimum number of leaves is 4 . Variables observed were leaf number, seedling height, seedling stem diameter, root length, primary root number, leaf chlorophyll content, relative water content (RWC) of leaves, the dry-oven weight of seedling, leaf $\mathrm{N}$ and $\mathrm{P}$ nutrient content, leaf carbohydrate content (reducing sugars and sucrose), and percentage of seedlings with the disease.

\section{Results and Discussions}

The results of the analysis of variance showed the interaction between the sizes of chopped corm and the types of soaking material (BR) significantly affected the height and dry-oven weight of seedling. The sizes of chopped corm (B) significantly influenced the number of leaves, leaves chlorophyll content, stem diameter of seedling, root length, and the number of primary roots, while the types of soaking material (R) significantly influenced leaf chlorophyll content, reducing sugar and leaf sucrose content.

The highest seedling height and dry-oven weight were obtained at $\mathrm{B}_{3} \mathrm{R}_{2}$ combination treatments were $113.67 \mathrm{~cm}$ and $54.09 \mathrm{~g}$, while the lowest at $\mathrm{B}_{1} \mathrm{R}_{2}$ namely $38.33 \mathrm{~cm}$ and $7.92 \mathrm{~g}$. In the types of soaking material $R_{0}, R_{1}, R_{2}$, and $R_{4}$, the highest seedling height and dry-oven weight were obtained at $B_{3}$, whereas in $R_{3}$, the highest was obtained in $B_{2}$ (Table 1 and Table 2). This showed that if using the type of soaking material $R_{0}, R_{1}, R_{2}$, and 
$\mathrm{R}_{4}$, the chopped corm used is a large size of $9 \times 9 \times 9 \mathrm{~cm}$, but if using $\mathrm{R}_{3}$, the chopped corm used is a medium size of $7 \times 7 \times 7 \mathrm{~cm}$. The results obtained in the immersion $R_{0}, R_{1}, R_{2}$, and $R_{4}$ following Firmansyah (2011) that the greater the size of the banana chopped corm the better the banana seedling, due to the larger chopped corm size the more food reserves contained to supply energy for buds grow and develop. According to Baiyeri \& Aba (2007), the differences of chopped corm on Kepok banana have a significant effect on the percentage of growth, seedling growth speed, number of roots and leafs, and seedling height. In $\mathrm{R}_{3}$, the height and dry-oven weight of seedling at $B_{3}$ was lower than that of $B_{2}$ is similar to the result of Safrizal (2013) that the larger size of chopped corm does not always show a better variable growth value than the smaller one. According to Supriana et al. (2015), in chopped corm of banana there is cytokinin hormone that can affect bud growth. Allegedly in $\mathrm{B}_{3}$, the concentration of the cytokinin hormone in the chopped corm is already high enough because the size of the chopped corm is greater than $B_{1}$ and $B_{2}$ so that with immersion in $R_{3}$ which there is cytokinin (BA) causes the cytokinin content in the $\mathrm{B}_{3}$ chopped corm to be to high or no optimal. The combination of $\mathrm{B}_{3} \mathrm{R}_{2}$ or soaked with the NAA hormone concentration of $100 \mathrm{ppm}$ for 1 minute has an impact on the ability of the chopped corm to produce the highest seedling height. The same result was also shown by Pratama (2012) on the propagation of pamelo with cuttings, that giving NAA hormone produced a higher percentage of growth, seedling height, and number of roots than those of control. The effectiveness of treated hormone immersion is influenced by many factors; one of them is the ability of planting material to absorb the immersion material, caused by the differences in the area of absorption. Naturally, there are endogenous hormones in the chopped corm, so the success rate of synthetic hormones from outside absorbed by chopped corm is greatly influenced by the accumulation of endogenous and exogenous hormones. If the content of endogenous hormones is sufficient, the additional exogenous hormones given will cause inhibition of the growth of certain organs due to excessive hormone accumulation (Mukarlina, 2018), but conversely, if little endogenous hormones and added hormones from outside (exogenous) can accelerate seedling growth (Zein, 2016).

Table 1

Effect of the differences of chopped corm sizes and the types of soaking material on seedling height

\begin{tabular}{cccccc}
\hline Treatment & \multicolumn{5}{c}{ Seedling height $(\mathrm{cm})$} \\
\cline { 2 - 6 } $\mathrm{s}$ & $\mathrm{R}_{0}$ & $\mathrm{R}_{1}$ & $\mathrm{R}_{2}$ & $\mathrm{R}_{3}$ & $\mathrm{R}_{4}$ \\
\hline $\mathrm{B}_{1}$ & $66.00 \mathrm{bc}$ & $81.00 \mathrm{ab}$ & $38.33 \mathrm{c}$ & $79.00 \mathrm{ab}$ & $89.00 \mathrm{ab}$ \\
$\mathrm{B}_{2}$ & $75.00 \mathrm{~b}$ & $69.33 \mathrm{bc}$ & $81.67 \mathrm{ab}$ & $99.33 \mathrm{ab}$ & $75.00 \mathrm{~b}$ \\
$\mathrm{~B}_{3}$ & $88.67 \mathrm{ab}$ & $101.33 \mathrm{ab}$ & $113.67 \mathrm{a}$ & $79.67 \mathrm{ab}$ & $102.67 \mathrm{ab}$ \\
\hline
\end{tabular}

Note: Numbers followed by the same letter in the same column and lane and diagonally showed no significant difference in Duncan's test of 5\%.

Table 2

Effect of the differences of chopped corm sizes and the types material of soaking on dry-oven weight of seedling

\begin{tabular}{cccccc}
\hline \multirow{2}{*}{$\begin{array}{c}\text { Treatmen } \\
\text { ts }\end{array}$} & \multicolumn{5}{c}{ Dry-oven weight of seedling (g) } \\
\cline { 2 - 5 } & $\mathrm{R}_{0}$ & $\mathrm{R}_{1}$ & $\mathrm{R}_{2}$ & $\mathrm{R}_{3}$ & $\mathrm{R}_{4}$ \\
\hline $\mathrm{B}_{1}$ & $22.68 \mathrm{bc}$ & $24.42 \mathrm{bc}$ & $7.92 \mathrm{c}$ & $27.15 \mathrm{~b}$ & $32.13 \mathrm{~b}$ \\
$\mathrm{~B}_{2}$ & $31.04 \mathrm{~b}$ & $25.40 \mathrm{bc}$ & $31.57 \mathrm{~b}$ & $44.70 \mathrm{ab}$ & $32.20 \mathrm{~b}$ \\
$\mathrm{~B}_{3}$ & $40.56 \mathrm{ab}$ & $48.93 \mathrm{ab}$ & $54.09 \mathrm{a}$ & $32.91 \mathrm{~b}$ & $46.22 \mathrm{ab}$ \\
\hline
\end{tabular}

Note: Numbers followed by the same letter in the same column and lane and diagonally showed no significant difference in Duncan's test of 5\%.

Different sizes of chopped corm have different effects on canopy and root growth of banana seedling. The differences in canopy growth can be seen from the number of leafs and stem diameter of the seedlings, while

Rai, I. N., Sudana, I. M., Astawa, I. N. G., \& Dwiyani, R. (2020). The effect of chopped corm sizes and types of soaking material on growth seedling of kepok banana (Musa paradisiaca L. ABB Kepok). International Journal of Life Sciences, 4(2), 32-41. https://doi.org/10.29332/ijls.v4n2.432 
the differences in root growth were reflected by the length of the root and the number of primary roots of the seedlings. In Table 3 can be seen, the greater the size of the chopped corm the greater number of leaf and diameter of the seedling stem produced. Similarly, root length and number of primary roots were also getting bigger. This condition proved that the larger size of the chopped corm will produce a better balance in the direction of seedling growth, that is not only increasing growth upwards (canopy) but also positively correlating to growth downwards (roots). The same results were shown by Dewi (2016) in the multiplication of banana, that larger size of splitted corm was able to increase canopy and root growth simultaneously. According to Putri (2017), difference sizes of chopped corm of banana causes has difference accumulation of carbohydrates and food reserves and its affect the ability and speed of the bud to grow and develop into seedling.

Improved canopy and root growth in larger chopped corm size was supported by higher leaf chlorophyll content and better ability to absorb nutrients and water. Although statistically was not significantly different, but the chlorophyll and RWC content of leaves in $\mathrm{B}_{3}$ were 46.89 SPAD and $82.06 \%$ tended to be higher than that of in $B_{1}$ and $B_{2}$ (Table 3). Likewise, the nutrient content of $N$ and $P$ leaves in $B_{1}, B_{2}$, and $B_{3}$ were not significantly different, but the value in $B_{3}$ tended to be higher than that of in $B_{1}$ and $B_{2}$ (Table 4 ). This supports the process of photosynthesis in seedlings from larger chopped corm size be running better, reflected by higher content of reducing sugars (Table 4). Data from this study indicated that larger chopped corm size will support buds to grow better than smaller one. Hutasoit et al. (2013) stated that the greater the size of planting.

Table 3

Effect of the differences of chopped corm sizes and types of soaking material on number of leaf, chlorophyil and RWC content of leaves, stem diameter, length of root, and number of primary roots.

\begin{tabular}{|c|c|c|c|c|c|c|}
\hline Treatments & $\begin{array}{l}\text { Leaf } \\
\text { number } \\
\text { (unit) }\end{array}$ & $\begin{array}{c}\text { Leaves } \\
\text { chlorophyil } \\
\text { content } \\
\text { (SPAD) }\end{array}$ & $\begin{array}{c}\text { Leaves } \\
\text { RWC (\%) }\end{array}$ & $\begin{array}{c}\text { Stem } \\
\text { diemeter } \\
(\mathrm{cm})\end{array}$ & $\begin{array}{l}\text { Root length } \\
\quad(\mathrm{cm})\end{array}$ & $\begin{array}{l}\text { Primary } \\
\text { root } \\
\text { number } \\
\text { (unit) }\end{array}$ \\
\hline \multicolumn{7}{|c|}{ Chopped corm sizes (B) } \\
\hline $\mathrm{B}_{1}$ & $6.07 \mathrm{~b}$ & $43.20 \mathrm{a}$ & $73.99 \mathrm{a}$ & $3.23 \mathrm{~b}$ & $65.40 \mathrm{~b}$ & $16.73 \mathrm{~b}$ \\
\hline $\mathrm{B}_{2}$ & $6.07 \mathrm{~b}$ & $46.64 \mathrm{a}$ & $80.83 \mathrm{a}$ & $3.99 \mathrm{a}$ & $65.93 \mathrm{~b}$ & $19.67 \mathrm{~b}$ \\
\hline $\mathrm{B}_{3}$ & $7.20 \mathrm{a}$ & $46.89 \mathrm{a}$ & $82.06 \mathrm{a}$ & $4.56 \mathrm{a}$ & $79.00 \mathrm{a}$ & $34.40 \mathrm{a}$ \\
\hline LSD $5 \%$ & 1.05 & 5.83 & 10.78 & 0.62 & 10.07 & 8.37 \\
\hline \multicolumn{7}{|c|}{ Types of soaking material (R) } \\
\hline $\mathrm{R}_{0}$ & $6.22 \mathrm{a}$ & $42.58 \mathrm{ab}$ & $73.75 \mathrm{a}$ & $3.77 \mathrm{a}$ & $60.00 \mathrm{a}$ & $21.00 \mathrm{a}$ \\
\hline $\mathrm{R}_{1}$ & $6.22 \mathrm{a}$ & $47.28 \mathrm{ab}$ & $79.12 \mathrm{a}$ & $4.02 \mathrm{a}$ & $67.56 \mathrm{a}$ & $20.11 \mathrm{a}$ \\
\hline $\mathrm{R}_{2}$ & $6.33 \mathrm{a}$ & $40.90 \mathrm{~b}$ & $76.69 \mathrm{a}$ & $3.66 \mathrm{a}$ & $74.00 \mathrm{a}$ & $24.78 \mathrm{a}$ \\
\hline $\mathrm{R}_{3}$ & $7.11 \mathrm{a}$ & $48.64 \mathrm{a}$ & $79.04 \mathrm{a}$ & $4.13 \mathrm{a}$ & 75.67 a & $23.33 \mathrm{a}$ \\
\hline $\mathrm{R}_{4}$ & $6.33 \mathrm{a}$ & $48.48 \mathrm{ab}$ & $86.12 \mathrm{a}$ & $4.04 \mathrm{a}$ & $68.33 \mathrm{a}$ & $28.78 \mathrm{a}$ \\
\hline LSD 5\% & 1.36 & 7.53 & 13.91 & 0.79 & 28.37 & 10.80 \\
\hline
\end{tabular}

Note: The number followed by the same letter in the same column showed a significantly different level of LSD test at $5 \%$. 
Table 4

Effect of the differences of chopped corm sizes and the types of soaking material on $\mathrm{N}$ and $\mathrm{P}$ leaf content, reducing sugar and sucrose content of leaves and percentage of seedlings affected by disease

\begin{tabular}{|c|c|c|c|c|c|}
\hline Treatments & $\begin{array}{c}\text { N leaf } \\
\text { content } \\
(\%)\end{array}$ & $\begin{array}{l}\text { P leaf } \\
\text { content } \\
(\%)\end{array}$ & $\begin{array}{c}\text { Leaf reducing } \\
\text { sugar content } \\
(\mathrm{mg} / \mathrm{g})\end{array}$ & $\begin{array}{c}\text { Leaf sucrose } \\
\text { content }(\mathrm{mg} / \mathrm{g})\end{array}$ & $\begin{array}{c}\text { Seedling } \\
\text { affected by } \\
\text { disease (\%)* }\end{array}$ \\
\hline \multicolumn{6}{|c|}{ Chopped corm sizes (B) } \\
\hline $\mathrm{B}_{1}$ & $1.87 \mathrm{a}$ & $0.58 \mathrm{a}$ & $5.50 \mathrm{~b}$ & $8.13 \mathrm{a}$ & 7 \\
\hline $\mathrm{B}_{2}$ & $1.77 \mathrm{a}$ & $0.64 \mathrm{a}$ & $6.74 \mathrm{a}$ & $7.42 \mathrm{a}$ & 20 \\
\hline $\mathrm{B}_{3}$ & $2.05 \mathrm{a}$ & $0.68 \mathrm{a}$ & $5.97 \mathrm{ab}$ & $7.78 \mathrm{a}$ & 20 \\
\hline LSD $5 \%$ & 0.30 & 0.17 & 1.07 & 1.19 & - \\
\hline \multicolumn{6}{|c|}{ Types of soaking material (R) } \\
\hline $\mathrm{R}_{0}$ & $1.70 \mathrm{a}$ & $0.55 \mathrm{a}$ & $4.47 \mathrm{~b}$ & $8.95 \mathrm{a}$ & 28 \\
\hline $\mathrm{R}_{1}$ & $2.09 \mathrm{a}$ & $0.68 \mathrm{a}$ & $5.69 \mathrm{ab}$ & $9.16 \mathrm{a}$ & 6 \\
\hline $\mathrm{R}_{2}$ & $1.86 \mathrm{a}$ & $0.68 \mathrm{a}$ & $4.88 \mathrm{ab}$ & $8.14 \mathrm{ab}$ & 28 \\
\hline $\mathrm{R}_{3}$ & $1.91 \mathrm{a}$ & $0.64 \mathrm{a}$ & $8.32 \mathrm{a}$ & $5.64 \mathrm{~b}$ & 6 \\
\hline $\mathrm{R}_{4}$ & $1.92 \mathrm{a}$ & $0.60 \mathrm{a}$ & $7.00 \mathrm{ab}$ & $6.97 \mathrm{~b}$ & 12 \\
\hline LSD 5\% & 0.39 & 0.22 & 1.38 & 1.54 & - \\
\hline
\end{tabular}

Note: The number followed by the same letter in the same column showed a significantly different level of LSD test at $5 \%$.

${ }^{*}$ data not statistical analyzed.

The material in mulberry propagation, the greater the speed of growth and height of seedlings. Rapilah et al. (2016) also found the same thing in a Sansievera nursery, that the larger cuttings size significantly increased the percentage of growth, height and number of seedlings than smaller one.

Soaking the chopped corm with the types of soaking material $R_{1}, R_{2}, R_{3}$ and $R_{4}$ resulted in higher number of leaf, RWC content of leaves, stem diameter, root length, number of primary roots and leaf $\mathrm{P}$ nutrient content than those of in $\mathrm{R}_{0}$ although statistically was not significantly different. This showed that soaking with Dithane M-45 fungicide and BA and/or NAA hormones can increase the growth of seedlings upward to form the canopy and downward to increase root growth. Soaking at $\mathrm{R}_{3}$ (BA hormone $75 \mathrm{ppm}$ ) gave the highest chlorophyil content that was 48.64 SPAD (Table 3). One of the functions of BA is to stimulate chlorophyll synthesis and prevent aging (senescence). According to Baihaqi (2017) the usage BA hormone is able to stimulate the growth of buds that will become the organ of the leaf to synthesize chlorophyll as a place for photosynthesis; in addition treatment of cytokines can stimulate the process of cell division and the formation of axillary buds.

Soaking the chopped corm with different types of soaking material affected the reducing sugar and leaf sucrose content. The highest leaf reducing sugar content obtained at $R_{3}(8.32 \mathrm{mg} / \mathrm{g})$ and was significantly different with the lowest leaf reducing sugar content at $R_{0}(4.47 \mathrm{mg} / \mathrm{g}$ ), but not significantly different with leaf reducing sugar content at $R_{1}, R_{2}$, and $R_{4}$. On the other hand, leaf sucrose content was lowest at $R_{3}(5.64 \mathrm{mg} / \mathrm{g}$ ) and significantly different with leaf sucrose content at $R_{0}(8.95 \mathrm{mg} / \mathrm{g})$. In general, soaking chopped of corm with soaking material containing hormones $\left(\mathrm{R}_{2}, \mathrm{R}_{3}\right.$, and $\left.\mathrm{R}_{4}\right)$ decreased the leaf reducing sugar content, but increased the leaf sucrose content (Table 4). The data showed that the immersion of chopped corm with soaking material containing BA and/or NAA caused higher accumulation of reducing sugar (sugar forms in photosynthesis) than that of without hormone, but the sucrose content as sugar that is easily translocated shows the opposite results. Based on these data, it is suspected that in banana nurseries a form of sugar that is easily transported (sucrose) is not stored for a long time in the leaves, but is immediately used for growth and metabolic processes. Increased growth and metabolic processes in seedlings that got BA and/or NAA hormone immersion were shown by the

Rai, I. N., Sudana, I. M., Astawa, I. N. G., \& Dwiyani, R. (2020). The effect of chopped corm sizes and types of soaking material on growth seedling of kepok banana (Musa paradisiaca L. ABB Kepok). International Journal of Life Sciences, 4(2), 32-41. https://doi.org/10.29332/ijls.v4n2.432 
higher number of leafs, leaf RWC, stem diameter, root length, and number of primary roots. Physiologically plants that are at the nursery stage (vegetative growth), most of the dominant photosynthesis results are used for growth rather than stored in the tissue so that the accumulation of sucrose in the leaves will be lower, because the sugar is sent to the growing meristematic tissues (tip of the buds and root). According to Liu et al. (2012), sucrose is a form of sugar that is generally transported in phloem by most plants.

Soaking the chopped corm with Dithane M-45 is quite effective in reducing the percentage of seedlings affected by the disease. This can be seen from the percentage of seedlings attacked by disease in $R_{1}$, $R_{3}$, and $R_{4}$ respectively 6,6 , and $12 \%$ while in $\mathrm{R}_{0}$ (control) reaches $28 \%$. The active ingredient contained in the Dithane $\mathrm{M}$ 45 is mankozeb, which works by chalking the elements needed by the pathogen so that the growth of the pathogen is inhibited. In addition, the active ingredient is able to initiate the formation of metabolites in plant physiologically into isothiocinates which activate enzymes so that the development of amino acid synthesis of pathogenic organisms is inhibited and not developed (Sumardiyono, 2008). However, soaking with Dithane M45 was not able to produce seeds that $100 \%$ disease-free. It is estimated because Dithane M- 45 is a type of fungicide which works through contact so that its ability for protection and mold growth inhibition is limited. If the plant material contains systemic disease inoculum, contact fungicides tends to fail to overcome it. The same results were obtained by Firmansyah (2011) that treatment with contact fungicides in banana nurseries has not been able to produce fully healthy seedlings.

\section{Conclusion}

The combination treatment of $9 \times 9 \times 9 \mathrm{~cm}$ chopped corm size and soaking with Dithane M-45 $2 \mathrm{~g} / \mathrm{l}+\mathrm{BA}$ hormone 75 ppm gave the highest growth of Kepok banana seedling, indicated by the highest height and dryoven weight of seedling. As a single factor, the greater size of the chopped corm, the greater number of leaf, diameter of stem, root length and number of primary roots produced. Soaking the chopped corm with material containing BA and/or NAA hormones increased growth canopy and roots, while soaking with material containing Dithane $\mathrm{M}-45$ reduces the percentage of seedlings affected by the disease.

\section{Acknowledgments}

Our gratitude goes to the Udayana University for the funds provided through Udayana Invention Grants in 2020. Many thank to I Gede Jaya Hahendra for his assistance in carrying out the research. The authors also would like to thank the reviewer for their consideration of the further process of the present paper. Thanks to the editor of IJLS for the valuable support, time as well as advice. 


\section{References}

Avivi, S., Soedarmo, S. H., \& Prasetyo, P. A. (2015). Multiplikasi tunas dan aklimatisasi tiga varietas pisang: Raja Nangka, Kepok, dan Mas. Jurnal Hortikultura Indonesia, 4(2), 83-89.

Baihaqi, H. (2017). Pengaruh Teknik Penyemaian Dan Konsentrasi Benzil-Adenin (Ba) Pada Pertumbuhan Bibit Manggis (Garcinia mangostana L.) Asal Biji.

Baiyeri, K. P., \& Aba, S. C. (2007). A review of protocols for macropropagation in Musa species. Fruit, Veg. Cereal Sci. Biotech, 1, 110-15.

Bhende, S.S. \& S. Kurien. (2015). Sucker Production in Banana. Journal of Tropical Agriculture 53(2), 97-106.

Borges, M. H., Alves, D. L. F., Raslan, D. S., Piló-Veloso, D., Rodrigues, V. M., Homsi-Brandeburgo, M. I., \& De Lima, M. E. (2005). Neutralizing properties of Musa paradisiaca L.(Musaceae) juice on phospholipase A2, myotoxic, hemorrhagic and lethal activities of crotalidae venoms. Journal of ethnopharmacology, 98(1-2), 21-29. https://doi.org/10.1016/j.jep.2004.12.014

Carmona-Garcia, R., Sanchez-Rivera, M. M., Méndez-Montealvo, G., Garza-Montoya, B., \& Bello-Pérez, L. A. (2009). Effect of the cross-linked reagent type on some morphological, physicochemical and functional characteristics of banana starch (Musa paradisiaca). Carbohydrate Polymers, 76(1), 117-122. https://doi.org/10.1016/j.carbpol.2008.09.029

Castillo-Israel, K. A. T., Baguio, S. F., Diasanta, M. D. B., Lizardo, R. C. M., Dizon, E. I., \& Mejico, M. I. F. (2015). Extraction and characterization of pectin from Saba banana [Musa'saba'(Musa acuminata x Musa balbisiana)] peel wastes: A preliminary study. International Food Research Journal, 22(1).

Convention on Biological Diversity. 2017. Indonesia-Country Profile. https://www. cbd.int/

Deptan (Departemen Pertanian). 2020. Pisang. Outlook Komoditas Pertanian Sub Sektor Hortikultura. Pusat Data dan Sistem Informasi Pertanian Kementerian Pertanian.

Dewi, N. (2016). Pengaruh Ukuran Belahan Bonggol terhadap Pertumbuhan Bibit Pisang Raja (Musa paradisiaca L.). Laporan Penelitian Dosen. Fakultas Pertanian, Universitas Baturaja, Baturaja. P.37

FAO (Food and Agriculture Organization). 2018. Post-harvest Management of Banana for Quality and Safety Assurance. Guidance for horticultural supply chain stakeholders. Food and Agriculture Organization of the United Nations (FAO). Viale delle Terme di Caracalla 00153 Rome, Italy. www.fao.org.

Firmansyah, I. (2011). Penentuan ukuran dan teknik penyimpanan Benih pisang kepok (Musa sp. Abb group) dari bonggol. Institut Pertanian Bogor.

Hutasoit, R., Simon, G., \& Andi, T. (2013). Pengaruh diameter stek batang terhadap pertumbuhan bibit pada empat spesies tanaman murbei (Morus sp).

Kasrina, K. (2013). Pisang Buah (Musa Spp): Keragaman Dan Etnobotaninya Pada Masyarakat Di Desa Sri Kuncoro Kecamatan Pondok Kelapa Kabupaten Bengkulu Tengah. Prosiding SEMIRATA 2013, 1(1).

Kishor, R. (2017). High-performance piezoelectric nanogenerators composed of formamidinium lead halide perovskite nanoparticles and poly (vinylidene fluoride). Nano Energy, 37, 126-135.

Liu, D. D., Chao, W. M., \& Turgeon, R. (2012). Transport of sucrose, not hexose, in the phloem. Journal of Experimental Botany, 63(11), 4315-4320. https://doi.org/ 10.1093/jxb/ers127

Mahfudza, E., Mukarlina, R. Linda. (2018). Perbanyakan Tunas Pisang Cavendish (Musa acuminata L.) Secara In Vitro dengan Penambahan Naphthalene Acetic Acid (NAA) dan Air Kelapa. Jurnal Protobiont 7(1), 75-79.

Muasya, R. M., Kasyoka, M. R., Mwangi, M., Kori, N., \& Gitonga, N. (2010). Evaluating the macropropagation efficiency of banana varieties preferred by farmers in Eastern and Central Kenya.

Mukarlina, F., R. Linda. (2018). Respon Pertumbuhan Tunas Mahkota Nanas (Ananas Comosus L. Merr.) dengan Penambahan Benzyl Amino Purine (BAP) dan naphthaline acetic acid (NAA). Jurnal Protobiont 7(1), 69-74

Nunez-Santiago, M. C., Bello-Perez, L. A., \& Tecante, A. (2004). Swelling-solubility characteristics, granule size distribution and rheological behavior of banana (Musa paradisiaca) starch. Carbohydrate polymers, 56(1), 65-75. https://doi.org/10.1016/j.carbpol.2003.12.003

Nyawira, S. S., Nabel, J. E., Brovkin, V., \& Pongratz, J. (2017). Input-driven versus turnover-driven controls of simulated changes in soil carbon due to land-use change. Environmental Research Letters, 12(8), 084015.

Parmar, H. S., \& Kar, A. (2007). Protective role of Citrus sinensis, Musa paradisiaca, and Punica granatum peels against diet-induced atherosclerosis and thyroid dysfunctions in rats. Nutrition Research, 27(11), 710-718. https://doi.org/10.1016/j.nutres.2007.09.003

Rai, I. N., Sudana, I. M., Astawa, I. N. G., \& Dwiyani, R. (2020). The effect of chopped corm sizes and types of soaking material on growth seedling of kepok banana (Musa paradisiaca L. ABB Kepok). International Journal of Life Sciences, 4(2), 32-41. https://doi.org/10.29332/ijls.v4n2.432 
Pelissari, F. M., Andrade-Mahecha, M. M., do Amaral Sobral, P. J., \& Menegalli, F. C. (2013). Comparative study on the properties of flour and starch films of plantain bananas (Musa paradisiaca). Food Hydrocolloids, 30(2), 681-690. https://doi.org/10.1016/j.foodhyd.2012.08.007

Prabawati, S., Suyanti, S., \& Setyabudi, D. A. (2008). Teknologi Pascapanen dan Pengolahan Buah Pisang. In Balai Besar Penelitian dan Pengembangan Pascapanen Pertanian. Seminar Badan Litbang Pertanian. Departemen Pertanian. Bogor.

Prabhuling, G., \& Sathyanarayana, B. N. (2017). Optimization of explants density for tissue culture propagation of banana cv.'Grande Naine'. International Journal of Agricultural Sciences, 13(1), 71-76.

Pratama, N.B. (2012). Pengaruh Zat Pengatur Tumbuh NAA dan IBA Terhadap Pembentukan Akar dan Tunas Stek Jeruk Pamelo (Citrus grandis L. Osbeck.). Skripsi. Departemen Agronomi dan Hortikultura, Fakultas Pertanian Institut Pertanian Bogor, Bogor. p.51.

Putri, D.M.S. (2017). Pengaruh Konsentrasi Rootone-f dan Panjang Setek pada Pertumbuhan Rhododendron mucronatum G. Don. var. phoeniceum. Jurnal Biologi Udayana 21(1), 35-39

Rai, I. N., Dwivany, F. M., Sutanto, A., Meitha, K., Sukewijaya, I. M., \& Ustriyana, I. N. G. (2018). Biodiversity of Bali Banana (Musaceae) and its Usefulness. HAYATI Journal of Biosciences, 25(2), 47.

Rapilah, R., Rahayu, A., \& Rochman, N. (2016). Pertumbuhan Setek Sansevieria cylindrica 'Skyline'pada Berbagai Ukuran Bahan Tanaman dan Komposisi Media Tanam. JURNAL AGRONIDA, 2(1).

Reginio Jr, F. C., Ketnawa, S., Shiina, T., \& Ogawa, Y. (2018). Effect of maturity on in vitro starch digestibility of Saba banana [Musa 'saba'(Musa acuminata x Musa balbisiana)]. Journal of Food Science and Agricultural Technology (JFAT), 4, 23-28.

Safrizal, S. (2013). Studi Perbanyakan Vegetatif Pisang Raja Waak (Musa SP.) Dengan Induksi Bonggol: Pengaruh Bobot Stek Bonggol. Jurnal Edukasi dan Sains Biologi, 2(1), 77232.

Saputra, R. U. (2016). Pengaruh Jenis Bonggol Dan Konsentrasi Ba (Benziladenin) Terhadap Pertumbuhan Vegetatif Tanaman Pisang (Musa paradisiaca Linn) Kepok Kuning.

Sukowardana, A., Kushendarto, K., \& Rugayah, R. (2015). Pengaruh Jenis Bonggol dan Konsentrasi Ba terhadap Pertumbuhan Vegetatif P pada Tanaman Pisang Kepok Manado. Jurnal Penelitian Pertanian Terapan, 15(3).

Sumardiyono, C. (2008). Ketahanan jamur terhadap fungisida di Indonesia.Jurnal Perlindungan Tanaman Indonesia, 14(1), 1-5.

Supriana, I. K. A., Wijana, G. E. D. E., \& Raka, I. G. N. (2015). Pengaruh sumber bonggol dan media tanam pada pembibitan tanaman pisang kayu (Musa paradisiacaL. cv. Kayu). Agroekoteknologi Tropika, 4(2), $124-134$.

Tumuhimbise, R., \& Talengera, D. (2018). Improved Propagation Techniques to Enhance the Productivity of Banana (Musa spp.). Open Agriculture, 3(1), 138-145. https://doi.org/10.1515/opag-2018-0014.

Valentine, V., Sutedja, A. M., \& Marsono, Y. (2015). pengaruh konsentrasi na-cmc (natrium-carboxymethyl cellulose) terhadap karakteristik cookies tepung pisang kepok putih (Musa paradisiaca L.) PREGELATINISASI. Jurnal Agroteknologi, 9(02), 93-101.

Windarti, W. (2009). Keanekaragaman genetika pisang bergenom B berdasarkan penanda mikrosatelit. Biosaintifika: Journal of Biology \& Biology Education, 1(1).

Zein, A. (2016). Zat Pengatur Tumbuh Tanaman (Fitohormon). Padang. Penerbit Kencana. p.166. 


\section{Biography of Authors}

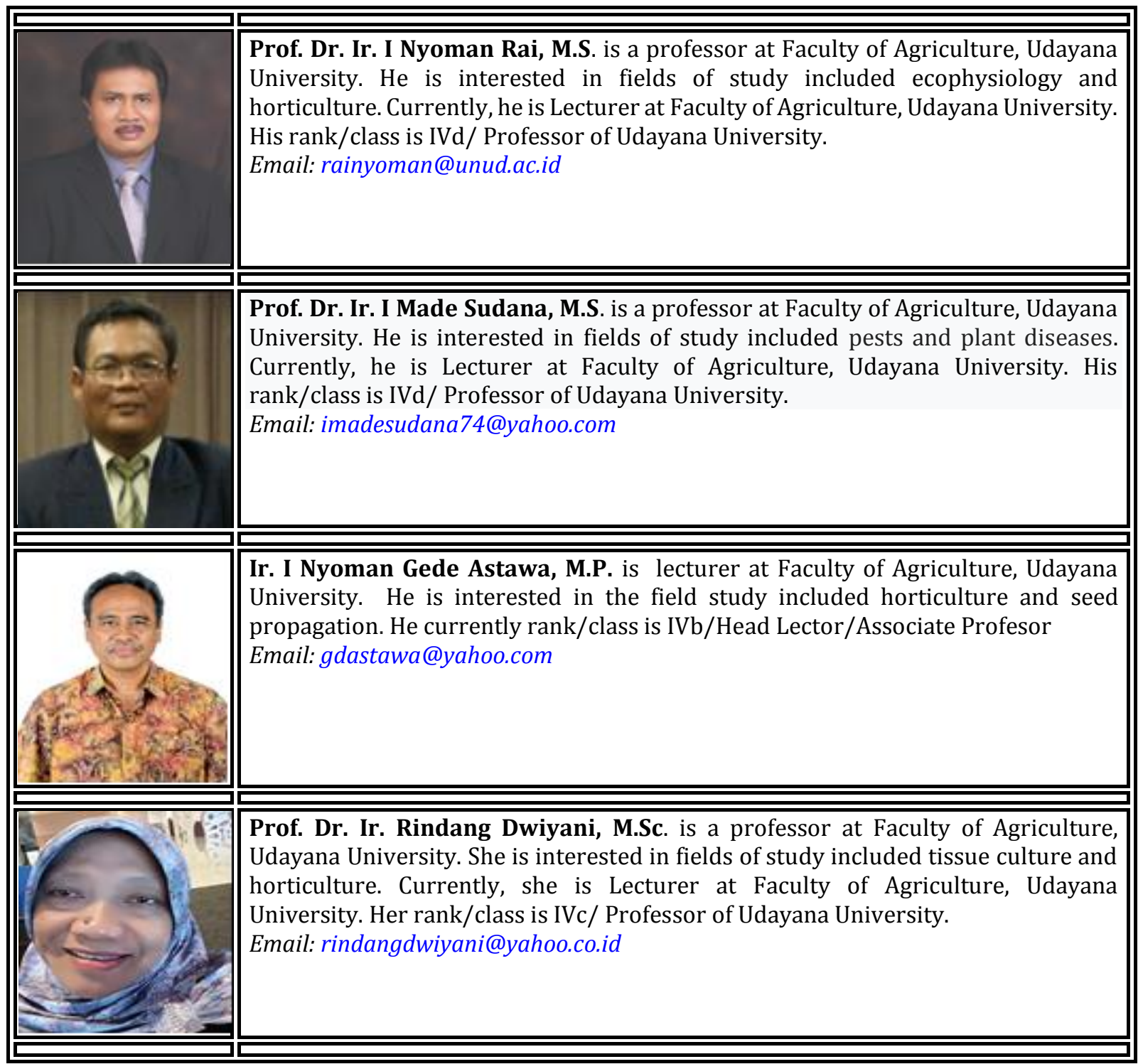

Rai, I. N., Sudana, I. M., Astawa, I. N. G., \& Dwiyani, R. (2020). The effect of chopped corm sizes and types of soaking material on growth seedling of kepok banana (Musa paradisiaca L. ABB Kepok). International Journal of Life Sciences, 4(2), 32-41. https://doi.org/10.29332/ijls.v4n2.432 